\title{
ИЗУЧЕНИЕ ПРИВИТОЙ СОПОЛИМЕРИЗАЦИИ ХИТОЗАНА С ЧЕТВЕРТИЧНЫМИ АММОНИЕВЫМИ СОЛЯМИ
}

\author{
А.Д. Мороз, С.С. Дрябина, Ю.В. Шулевич, И.А. Новаков \\ Волгоградский государственный технический университет, \\ 400005, Россия, г. Волгоград, пр.им. В.И.Ленина, 28. \\ DOI: 10.19163/MedChemRussia2021-2021-393 \\ E-mail: nastamoroz01@gmail.com
}

Хитозан является уникальным поликатионом, интерес к которому в последние годы возрастает. Благодаря биосовместимости, биодеградации, гиппоаллергенности и низкой токсичности производные хитозана находят широкое применение в медицине в качестве ингредиентов лекарственных препаратов, обладающих антибактериальными и биоцидными свойствами. Полиэлектролитная природа хитозана позволяет использовать его для коагуляции бактериальных клеток, для создания пленочных материалов, совместимых с тканями человека и животных. Основной проблемой при использовании хитозана является его нерастворимость в воде при биологических значения $\mathrm{pH}$ (5-7). Поэтому актуальны исследования по увеличению растворимости хитозана в нейтральной среде [1]. Множество работ посвящено модификации молекул хитозана за счет введения различных функциональных групп по $-\mathrm{OH}$ и $-\mathrm{NH}_{2}$ группам. С целью получения высокомолекулярных производных хитозана перспективным представляется привитая полимеризация, позволяющая на стадии синтеза направленно контролировать молекулярную массу и величину катионного заряда [2]. Нами предложено использование метода контролируемой радикальной полимеризации ATRP для получения сополимера хитозана с катионным сомономером - триметилоксиэтилметакрилоиламмоний метилсульфатом.

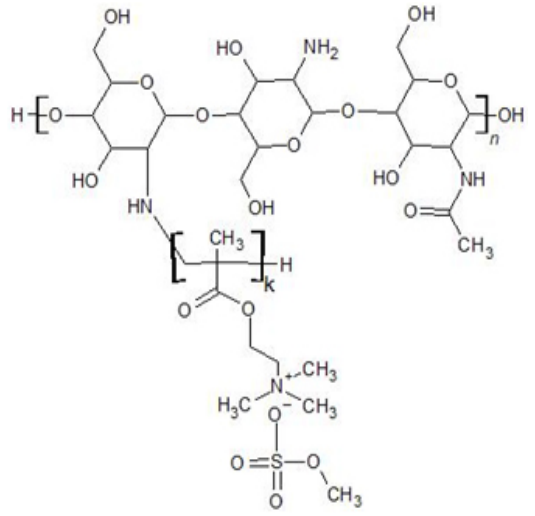

Хитозан выступает в качестве «макроинициатора», возбуждающего радикальную полимеризацию добавляемого в реакционную смесь мономера. При этом следует ожидать улучшения растворимости сополимера. Наличие четвертичных аммониевых групп способствует проявлению антимикробных свойств, повышение положительных зарядов увеличивает флоккулирующие свойства на отрицательно заряженные биологические ткани. Полученный сополимер, обладая высокой гидрофильностью, может применяться в качестве полупроницаемых мембран и покрытий.

\section{Литература}

[1] В.Е. Камская, Научное обозрение. Биологические науки. 2016, № 6. - С. 36-42.

[2] В.П. Варламов, А.В. Ильина, Б. Ц. Шагдарова, А. П. Луньков, И. С. Мысякина. Успехи биологической химии. 2020. т.60. - С. 317-368.

$$
-393-
$$

